\title{
Enzymologic and Metabolic Studies in Two Families Affected by Argininosuccinic Aciduria
}

\author{
I. A. QURESHI, J. LETARTE, (41) R. OUELLET, AND B. LEMIEUX \\ Centre de Recherche Pédiatrique, Hôpital Sainte-Justine and Université de Montréal, Montréal; Département de \\ Pédiatrie, Centre Hospitalier Universitaire, Université de Sherbrooke, Québec, Canada
}

\begin{abstract}
Summary
Both the affected families studied provide another example of the autosomal recessive inheritance of argininosuccinic aciduria. The fasting plasma levels of argininosuccinic acid in the two propositi did not correlate with the levels of argininosuccinic acid lyase (ASAL) in erythrocytes. There was $210 \mu \mathrm{M}$ argininosuccinic acid with indications of anhydride $B$ content in the family I propositus, having an enzyme activity of $13 \%$; while the family II propositus gave an argininosuccinic acidemia reading of $64.6 \mu \mathrm{M}$ with no activity of RBC ASAL. There was a reduced enzyme activity in all the members of affected families due to a significantly reduced $V_{\max }$ value as compared to control. Within family I, the differences were solely determined by the $V_{\max }$ of the enzymes. In family II, the two siblings had a significantly reduced $K_{m}$ value as compared to the parents (0.09 and 0.10 against 0.16 and $0.18 \mathrm{mM}$ ).

Plasma citrulline and glutamine were generally elevated in the two affected families, particularly in the propositi, whereas arginine was normal. A dietary protein-loading trial conducted on members of family II showed more urinary ammonia and $\alpha$ amino nitrogen excretion as compared to a control family, while urea excretion was comparable. Only the propositus showed a urinary excretion of argininosuccinic acid.
\end{abstract}

\section{Speculation}

Research work on the structural and kinetic characterization of human ASAL from various organs and tissues may throw light on the importance of RBC enzyme in the pathogenesis and diagnosis of argininosuccinic aciduria. Such studies will also help in clarifying the regulatory gene hypothesis of ASAL activity in various organs.

Argininosuccinic aciduria, a metabolic disorder of the urea cycle, caused by the deficiency of the enzyme L-argininosuccinic acid lyase (EC 4.3.2.1), is now a well known disease entity (11, $29,32)$. Its incidence in newborn screening programs is variously quoted at 1 in 250,000 births (29) to 1 in 70,000 (23). In the Quebec Network for Genetic Medicine program of mass screening for amino acid disorders, two confirmed cases have been discovered; another was found to have transitory argininosuccinic aciduria, and one newborn is under investigation. This is an incidence of 1 in 80,000 newborns in the Province of Quebec in the population tested since $1973(20)$.

Since first reported in 1958 (3), observations on 51 children showing argininosuccinic acid excretion and two affected fetuses have appeared in the literature, giving this disease the most extensive incidence amongst hereditary hyperammonemic disorders. The published observations include 32 cases studied in respect of ASAL deficiency in liver, kidney, brain, cultured fibroblasts, or red blood cells. However, the enzyme has been studied mostly in erythrocytes because of its easy accessibility and observed deficiency in the diseased state $(4,9,19,26,31,36)$.
Familial studies on argininosuccinic aciduria have also generally employed ASAL activity measurements in red blood cells. It has been possible to identify the heterozygous or normal relatives of the patient on the basis of the level of active enzyme in erythrocytes $(5,7,8,14-17,21,22,25,30,35)$.

As a part of the Quebec Network of Genetic Medicine program in 1973 we studied two families of French-Canadian origin in which, on routine neonatal screening, one child in each was discovered to excrete argininosuccinic acid. The diagnosis was confirmed by follow-up studies and erythrocyte enzyme measurement in early 1975 . This paper describes the results of the familial biochemical, nutritional, and enzymologic studies undertaken recently.

\section{SUBJECTS AND CONTROLS}

Affected family $I$ is composed of father and mother ages 35 and 31 , male and female siblings ages 9 and 8 , and a male propositus born November 6,1973 . Family II is composed of father and mother ages 40 and 33, female and male siblings ages 10 and 7 and a female propositus born September 14, 1973. No blood sample was received for the female sibling in family I.

The control for enzymologic studies was a healthy male adult. For nutritional investigation, the control family was carefully selected for comparison with family II, considering the composition and age of family members and availability of children of both sexes. Interassay variation was avoided by analysing all samples from subjects and controls in the same batch against common standards.

\section{METHODS}

ENZYMOLOGIC STUDIES

The activity of erythrocyte ASAL was measured on the basis of the method proposed by Takahara and Natelson (34). This method was considered more accurate than the method generally reported in literature (35), since it measures the direct product of the enzymatic reaction. It is sensitive to lower levels of enzyme activity and more suited to kinetic studies because no coupling enzyme is involved. The substrate contained argininosuccinic acid $\left(\mathrm{Na}^{+}\right.$salt), buffered to $\mathrm{pH} 7$ with phosphate, 0.2 M. Ethylenediaminetetraacetate (EDTA), $0.2 \mathrm{M}$, was added to inhibit arginase by complexing manganese $\left(\mathrm{Mn}^{++}\right)$and other metals. Hemolyzed erythrocytes were incubated for $1 \mathrm{hr}$, proteins were precipitated with trichloroacetic acid, and arginine was measured by the application of the Sakaguchi reaction to the filtrate.

Fasting samples of 5-7 ml blood were collected in heparinized Vacutainer tubes by venipuncture and immediately stored at $4^{\circ}$ until centrifuged. Enzyme activity was measured within $24 \mathrm{hr}$ of sampling, since whole blood samples have been found to retain erythrocyte ASAL activity up to $24 \mathrm{hr}$. Hemolysates of washed and packed erythrocytes were prepared in distilled water (dilution $1: 5$ ) by repeated freezing and thawing in Dry Ice-methanol 
mixture. This method for achieving hemolysis was preferred to the saponin solution used in the original technique (34) due to possible interference in kinetic studies. For point activity measurement, the same final substrate concentration $(0.4 \mathrm{mM})$ was used as recommended in the original method.

In kinetic study measurements, final substrate concentrations ranging from $0.031-1.56 \mathrm{mM}$ were utilized, as compared to 0.1-1.6 mM deduced from the original article. Each substrate level was run in duplicate tubes. Incubation time was kept at 1 hr because of the lower enzyme activity expected in the samples received. The method has been showing good linearity up to $1 \mathrm{hr}$ in earlier studies. This technique for erythrocyte ASAL measurement has consistently shown good reproducibility in our laboratories. The coefficient of variation (CV) for point activity measurement has always been less than $8 \%$, whereas the $\mathrm{CV}$ for $\mathrm{K}_{\mathrm{m}}$ and $\mathrm{V}_{\max }$ studies was calculated to be $4.5 \%$ and $3.7 \%$, respectively. Erythrocyte arginase was measured by the modification of the Tomlinson and Westall technique (35), proposed by Shih et al. (33). Hemoglobin content in packed erythrocytes was determined by the Cyanmethemoglobin method, utilizing a commercial kit (Hycel cyanmethemoglobin reagent, Hycel, Inc., Houston, TX).

Kinetic data was plotted in the form of Lineweaver-Burk plots $(1 /(\mathrm{S}): 1 / \mathrm{v})$ to obtain $-1 / \mathrm{K}_{\mathrm{m}}$ on the $\mathrm{x}$-intercept, $1 / \mathrm{V}$ on the $\mathrm{y}$ intercept and $\mathrm{K}_{\mathrm{m}} / \mathrm{V}$ on the slope of the regression line. The data were also analyzed by the Hofstee method $(\mathrm{v} /(\mathrm{S}): \mathrm{v})$ to obtain $-K_{m}$ on the slope and by Hanes method ((S):(S)/v) to get $1 / \mathrm{V}$ on the slope (12). The different methods of plotting and analysis were used to isolate various parameters on the slope for statistical comparison. The $t$-test for the comparison of slopes was taken from Dixon and Massey (13).

\section{MEASUREMENT OF PLASMA AMINO ACIDS AND UREA}

The plasma obtained after erythrocyte separation was kept frozen at $-20^{\circ}$ (Dry Ice) until sent for amino acid analysis. Quantitative amino acid determination was done on an automatic TSM amino acid analyzer (Technicon Instrument Corp., Tarrytown, NY) with ion exchange columns. Plasma urea was measured by the diacetyl monoxime-antipyrine technique as adapted by Ceriotti (10).

\section{NUTRITIONAL AND METABOLIC STUDIES}

Members of family II, along with a selected control family, were given dietary load of protein through a normal supper intake. The mothers were interviewed in advance by a trained dietician to plan the test menu and receive necessary instructions for keeping intake records on special forms. The test menu, rich in meat and milk products, was designed to provide about 1.5$3.0 \mathrm{~g}$ of protein $/ \mathrm{kg}$ body wt. Intake of the meal was voluntary but was motivated towards maximum possible consumption. The family members were instructed to discard the urine voided just before supper. After the test meal, all urine samples were collected in special plastic bottles containing a small measured quantity of $0.1 \mathrm{~N}$ acetic acid to prevent decomposition of the $\mathrm{NH}^{+}{ }_{4}$ ion. Total collection was for about $12 \mathrm{hr}$, with the voiding just before breakfast included. A record of food intake was kept by the mother and delivered the next day along with urine samples.

Protein in the test supper was calculated on the basis of standard tables of food composition (2). Urinary urea nitrogen was measured by the modified Ceriotti technique (10). Creatinine was analyzed on a Beckman/Spinco model 150 ultramicroanalytical system by the alkaline picrate-picric acid technique of Jaffe (6). Urinary ammonia nitrogen was measured by a specific ammonia gas-sensing electrode (24) against ammonium chloride standard. These analyses were completed within $48 \mathrm{hr}$ of urine collection.

Urinary amino acids were analyzed by a technique based on ion-exchange column chromatography (TSM amino acid ana- lyzer, Technicon). Urinary orotic acid was measured by the technique of Adachi (1) as modified by Goldstein (18). $\alpha$ Amino nitrogen was determined by the spectrophotometric method of Wells (38).

\section{RESULTS}

\section{ACTIVITY OF ERYTHROCYTE ENZYMES}

Erythrocyte ASAL measurement in family I showed a residual activity of $13 \%$ in the propositus, whereas other family members had an activity ranging from $33-42 \%$ of the control value. In family II, the propositus showed no residual activity whereas parents and siblings had $36-45 \%$ of the control activity (Table 1).

The activity of erythrocyte arginase was somewhat reduced in the family I propositus, but tended to be normal in all other family members. The family II values at $1641-1812 \mu \mathrm{mol} \mathrm{urea} / \mathrm{g}$ $\mathrm{Hb} / \mathrm{hr}$ were also in the vicinity of control values at 1650 and our laboratory normal range of 1439-1952 $\mu \mathrm{mol} / \mathrm{g} \mathrm{Hb} / \mathrm{hr}$.

\section{ERYTHROCYTE ASAL KINETICS}

The values of $\mathrm{K}_{\mathrm{m}}$ and $\mathrm{V}_{\max }$ obtained by the Lineweaver-Burk plot of kinetic data are presented in Figure 1. As compared to the control value of $K_{m}(0.16)$, the figures are generally equivalent or slightly reduced. In family II, there is a considerable reduction of $K_{m}$ in the two siblings, being almost half that of the control. The $\mathrm{V}_{\max }$ picture is much more clear, with less than $50 \%$ of control value in members of both Families. Family I propositus shows the least $\mathrm{V}_{\max }$ at 0.8 as compared to 5.7 for

Table 1. Point activity of erythrocyte enzymes in affected families

\begin{tabular}{lccc}
\hline \multicolumn{1}{c}{ Subject } & $\begin{array}{c}\text { ASAL, } \mu \mathrm{mol} \\
\text { Arg/g Hb/hr }\end{array}$ & $\begin{array}{c}\text { ASAL, \% of } \\
\text { Control }\end{array}$ & $\begin{array}{c}\text { Arg, } \mu \mathrm{mol} \\
\text { urea/g Hb/hr }\end{array}$ \\
\hline Family I & & & \\
$\quad$ Father & 1.83 & 42 & 1778 \\
Mother & 1.73 & 40 & 1754 \\
Brother & 1.43 & 33 & 1727 \\
$\quad$ Propositus & 0.57 & 13 & 1154 \\
Family II & & & \\
$\quad$ Father & 1.68 & 39 & 1676 \\
Mother & 1.60 & 37 & 1641 \\
Brother & 1.57 & 36 & 1771 \\
Sister & 1.94 & 45 & 1666 \\
Propositus & Nil & & 1812 \\
Control & 4.36 & 100 & 1650 \\
\hline
\end{tabular}

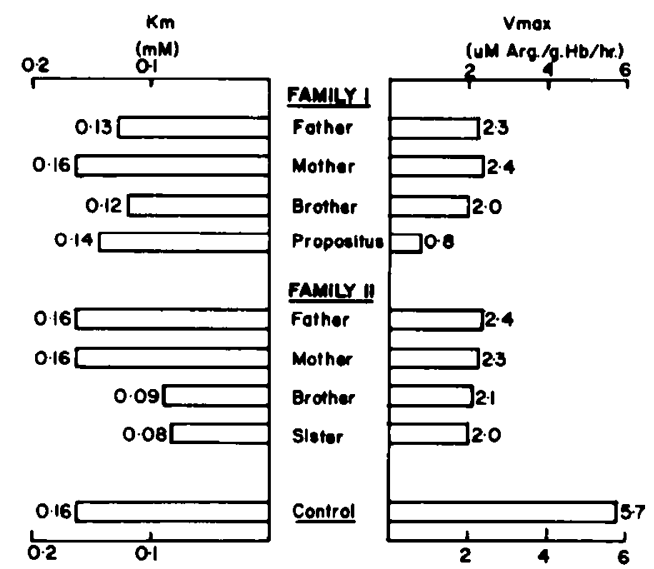

Fig. 1. $K_{m}$ and $V_{\max }$ values of RBC ASAL from various family members, obtained by calculation of data on the basis of LineweaverBurk plot. The control values are from a healthy male adult. 
the control. Kinetic study of the enzyme from the family II propositus was not possible because of no activity shown.

Figures 2 and 3 illustrate the differences in $K_{m}$ and $V_{\max }$ in members of the two families in the form of double reciprocal plots. In Figure 2 , there is a wide gap in the $1 / \mathrm{V}$ intercepts between the family $I$ propositus and father as well as the brother, whereas the $\mathrm{K}_{\mathrm{m}}$ values are apparently equivalent. In Figure $3, V_{\max }$ values are very near to each other, while the -1 / $\mathrm{K}_{\mathrm{m}}$ intercepts on the $\mathrm{x}$-axis are wide apart for the parents and siblings.

In order to verify and characterize the apparent differences between various members of the affected families, as brought out by the kinetic parameters of the double reciprocal plot, a statistical analysis was undertaken. The aim was to compare the slopes in the regression line of the plot, for which a relatively simple method is available (13). The slope of the LineweaverBurk plot corresponds to the mathematical value $K_{m} / V$, which is determined by both $\mathrm{K}_{\mathrm{m}}$ and $\mathrm{V}_{\max }$ variations. For this reason, we isolated the $K_{m}$ and $V_{\max }$ separately on the slope of the regression line, by calculating the data by two methods other than the Lineweaver-Burk plot, as outlined in Methods.

The calculated values of $K_{m}$ and $V_{\max }$, which are somewhat different than those shown in Figure 1 but show a similar trend, along with their statistical comparison ( $t$-test) are given in Table 2 . The $K_{m} / V$ comparison shows a significant difference between the control and the affected family members. There is a similar significant difference on comparing the slope corresponding to

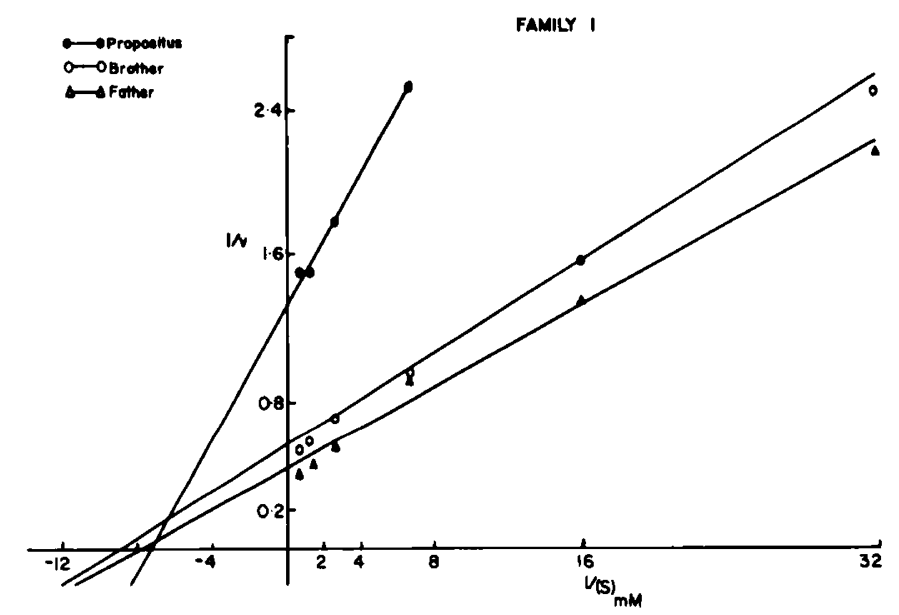

Fig. 2. Lineweaver-Burk plot of kinetic data from RBC ASAL of affected family $\mathbf{l}$. All points are means of duplicate determinations.

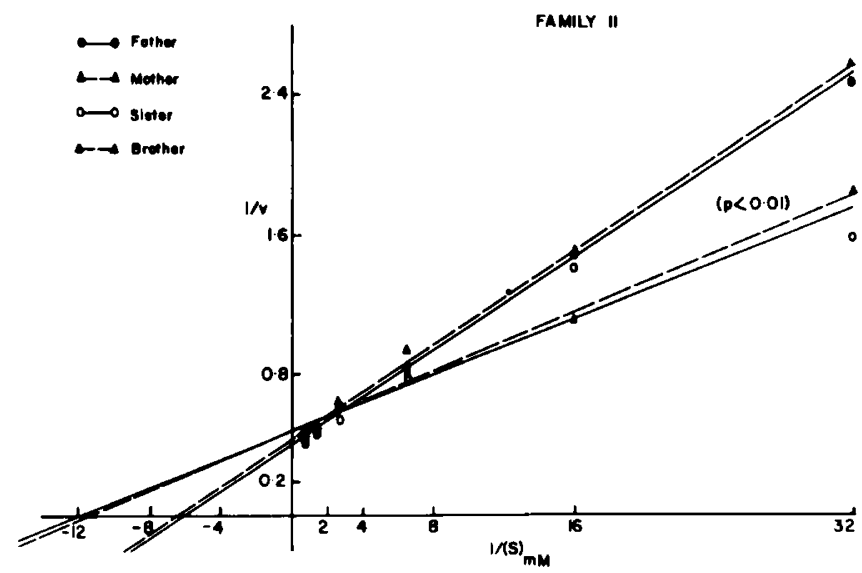

Fig. 3. Lineweaver-Burk plot of kinetic data from RBC ASAL of parents and siblings from affected family II. All points are means of duplicate determinations. $(P<0.01)$ : statistical comparison of slopes $\left(K_{m} / V\right)$.
Table 2. Statistical comparison of kinetic parameters from affected family members against control

\begin{tabular}{llll}
\hline \multicolumn{1}{c}{ Subject } & $\mathrm{K}_{\mathrm{m}} / \mathrm{V}$ & $\mathrm{K}_{\mathrm{m}}$ & $\mathrm{V}_{\max }$ \\
\hline Family I & & & \\
Father & $0.054^{1}$ & 0.16 & $3.2^{1}$ \\
Mother & $0.066^{1}$ & 0.17 & $2.7^{1}$ \\
Brother & $0.058^{1}$ & 0.14 & $2.4^{1}$ \\
$\quad$ Propositus & $0.183^{1}$ & 0.16 & $0.7^{1}$ \\
Family II & & & \\
Father & $0.066^{1}$ & 0.18 & $2.6^{2}$ \\
Mother & $0.067^{1}$ & 0.16 & $2.5^{1}$ \\
Brother & $0.042^{1}$ & 0.09 & $2.6^{1}$ \\
Sister & $0.040^{2}$ & 0.10 & $2.3^{2}$ \\
& & & \\
Control & 0.028 & 0.13 & 5.8 \\
\hline
\end{tabular}

$1 P<0.01$.

${ }^{2} P<0.05$.

Table 3. Statistical comparison of kinetic parameters within affected families ( $t$ values)

\begin{tabular}{lccc}
\multicolumn{1}{c}{ Comparison } & $\mathrm{b}=\mathrm{K}_{\mathrm{m}} / \mathrm{V}$ & $\mathrm{b}=-\mathrm{K}_{\mathrm{m}}$ & $\mathrm{b}=1 / \mathrm{V}$ \\
\hline Family I & & & \\
$\quad$ Father and mother & 1.39 & 0.31 & $3.08^{1}$ \\
Father and brother & 1.58 & 0.68 & $3.90^{1}$ \\
Father and propositus & $6.22^{1}$ & 0.17 & $33.37^{1}$ \\
Mother and brother & $3.02^{1}$ & 1.12 & 0.55 \\
Mother and propositus & $5.16^{1}$ & 0.37 & $29.74^{\prime}$ \\
$\quad$ Brother and propositus & $8.92^{1}$ & 0.03 & $32.16^{1}$ \\
Family II & & & \\
Father and mother & $5.15^{1}$ & 0.99 & 1.66 \\
Father and brother & $12.30^{1}$ & $5.70^{1}$ & 0.82 \\
Father and sister & $2.90^{1}$ & $3.39^{1}$ & 0.47 \\
Mother and brother & $11.33^{1}$ & $3.43^{1}$ & $1.91^{2}$ \\
Mother and sister & $5.26^{1}$ & $2.08^{2}$ & 0.50 \\
Brother and sister & 0.54 & 0.28 & 0.03 \\
\hline
\end{tabular}

${ }^{1} \mathrm{t} .99=2.896$

${ }^{2}$ t.95 $=1.860$.

$\mathrm{V}_{\max }$ value alone. However, the $\mathrm{K}_{\mathrm{m}}$ slope comparison does not show any significant differences.

A statistical comparison within the affected family members was also undertaken. Table 3 shows the $t$ values obtained on the comparison of slopes bearing $\mathrm{K}_{\mathrm{m}} / \mathrm{V}, 1 / \mathrm{V}$, or $-\mathrm{K}_{\mathrm{m}}$. In family $\mathrm{I}$, there was a significant difference in $\mathrm{K}_{\mathrm{m}} / \mathrm{V}$ between propositus and other members of the family and between the mother and brother. The $K_{m}$ value had no significant difference. However, all except one comparison of $V_{\max }$ value showed a significant difference. This indicates that within family $I$, all significant differences were determined by variations in $\mathrm{V}_{\max }$ alone.

In family II, there was a significant difference $(P<0.01)$ in all comparisons of $\mathrm{K}_{\mathrm{m}} / \mathrm{V}$, except between brother and sister. The $\mathrm{V}_{\max }$ comparison showed only one significant difference ( $P$ $<0.05$ ) between mother and brother. However, the $\mathrm{K}_{\mathrm{m}}$ comparison shows an interesting picture. There is no significant difference between two parents and within two siblings, whereas each parent compared to each sibling shows a significantly different $\mathrm{K}_{\mathrm{m}}$. This indicates that the family II differences are generally dictated by $K_{m}$ variation and that both the siblings have a different $K_{m}$ than both parents. This is in contrast to the situation in family I.

\section{PLASMA AMINO ACIDS IN AFFECTED FAMILIES}

Plasma aminograms of two families are represented in Tables 4 and 5 . There was an increased total plasma amino acid level in members of both families, particularly the propositi. The propositi of family I and II have argininosuccinic acidemia of the level of 210 and $64.6 \mu \mathrm{M}$, respectively. The plasma from 
Table 4. Plasma amino acid levels in family I (micromolar concentration)

\begin{tabular}{|c|c|c|c|c|c|c|}
\hline Amino acid & Father & Mother & Brother & Propositus & $\begin{array}{c}\text { Normal } 2-12 \\
\text { years }\end{array}$ & Normal adults \\
\hline Taurine & 245 & 197 & 167 & 209 & $60-110$ & $50-80$ \\
\hline Aspartic acid & 38.3 & 42.9 & 37.8 & 43.5 & $20-40$ & $10-40$ \\
\hline Threonine & 103 & 161 & 100 & 135 & $40-100$ & $90-140$ \\
\hline Serine & 155 & 150 & 141 & 214 & $80-110$ & $80-110$ \\
\hline Asparagine & 29.6 & 42.8 & 30.9 & 49.3 & $20-70$ & \\
\hline Glutamic acid & 320 & 139 & 175 & 143 & $20-250$ & $50-200$ \\
\hline Glutamine & 437 & 764 & 371 & 1373 & $150-720$ & \\
\hline Proline & 126 & 194 & 90.9 & 148 & $70-150$ & $150-250$ \\
\hline Glycine & 195 & 363 & 236 & 526 & $120-220$ & $150-240$ \\
\hline Alanine & 493 & 467 & 417 & 691 & $140-300$ & $350-370$ \\
\hline Citrulline & 49.6 & 47.4 & 65.8 & 240 & & $\operatorname{tr}-30$ \\
\hline$\alpha-\mathrm{NH}_{2}$-butyric acid & 35.2 & 11.0 & 9.2 & 14.8 & & $10-30$ \\
\hline Cystine & 1.3 & 2.6 & & 1.3 & & 0 \\
\hline Valine & 403 & 191 & 208 & 150 & $130-280$ & $50-80$ \\
\hline Methionine & 26.1 & 29.5 & 18.4 & 31.1 & $10-20$ & $10-40$ \\
\hline Isoleucine & 109 & 48.8 & 73.2 & 52.4 & $30-80$ & $50-80$ \\
\hline Leucine & 242 & 130 & 124 & 94.6 & $60-180$ & $100-140$ \\
\hline Tyrosine & 81.3 & 58.9 & 80 & 66.4 & $30-70$ & $40-70$ \\
\hline Phenylalanine & 82.5 & 60.7 & 54.8 & 46.5 & $30-60$ & $40-70$ \\
\hline Ornithine & 145 & 109 & 87.8 & 39.5 & $30-90$ & $580-900$ \\
\hline Lysine & 266 & 148 & 141 & 120 & $70-150$ & $160-180$ \\
\hline Histidine & 94.6 & 67.2 & 72.5 & 90.9 & $20-80$ & $60-70$ \\
\hline Carnosine & 7.7 & & & 7.7 & & \\
\hline Arginine & 94.6 & 63.6 & 84.6 & 50.3 & $20-90$ & $30-60$ \\
\hline Argininosuccinic acid & & & & 210 & & \\
\hline Anhydride B & & & & $\begin{array}{c}\text { Present } \\
\text { (qualitative) }\end{array}$ & & \\
\hline
\end{tabular}

Table 5. Plasma-aminoacid levels in family II (micromolar concentration)

\begin{tabular}{|c|c|c|c|c|c|c|c|}
\hline Amino acid & Father & Mother & Brother & Sister & Propositus & $\begin{array}{c}\text { Normal, } 2-12 \\
\text { years }\end{array}$ & Normal adults \\
\hline Taurine & 410 & 293 & 399 & 322 & 306 & $60-110$ & $50-80$ \\
\hline Aspartic acid & 26.3 & 21.7 & 76.7 & 37.3 & 46.5 & $20-40$ & $10-40$ \\
\hline Threonine & 180 & 137 & 161 & 150 & 93.2 & $40-100$ & $90-140$ \\
\hline Serine & 189 & 161 & 215 & 244 & 167 & $80-110$ & $80-110$ \\
\hline Asparagine & 48.6 & 20.1 & 39.4 & 57.5 & 12.8 & $20-70$ & \\
\hline Glutamic acid & 212 & 117 & 189 & 128 & 183 & $20-250$ & $50-200$ \\
\hline Glutamine & 725 & 526 & 588 & 911 & 548 & $150-720$ & \\
\hline Proline & 150 & 94.9 & 131 & 162 & 189 & $70-150$ & $150-250$ \\
\hline Glycine & 304 & 262 & 260 & 277 & 367 & $120-220$ & $150-240$ \\
\hline Alanine & 533 & 369 & 385 & 445 & 363 & $140-300$ & $350-370$ \\
\hline Citrulline & 89.3 & 68.6 & 83.7 & 133 & 173 & & $\operatorname{tr}-30$ \\
\hline $\begin{array}{l}\alpha-\mathrm{NH}_{2} \text {-butyric acid } \\
\text { Cystine }\end{array}$ & 3.8 & 3.2 & 14.8 & 19.3 & 2.4 & & $\begin{array}{c}10-30 \\
0\end{array}$ \\
\hline Valine & 306 & 190 & 344 & 323 & 205 & $130-280$ & $50-80$ \\
\hline Methionine & 30.7 & 157 & 27.6 & 38.9 & 69.5 & $10-20$ & $10-40$ \\
\hline Isoleucine & 89.7 & 49.5 & 111 & 100 & 47.2 & $30-80$ & $50-80$ \\
\hline Leucine & 185 & 118 & 195 & 222 & 121 & $60-180$ & $100-140$ \\
\hline Tyrosine & 81.9 & 62.1 & 96.2 & 125 & 66.7 & $30-70$ & $40-70$ \\
\hline Phenylalanine & 58.6 & 51.1 & 75.1 & 93.9 & 76.0 & $30-60$ & $40-70$ \\
\hline Ornithine & 116 & 113 & 133 & 132 & 229 & $30-90$ & $580-900$ \\
\hline Lysine & 185 & 184 & 195 & 228 & 138 & $70-150$ & $160-180$ \\
\hline Histidine & 89.5 & 61.4 & 77.2 & 90.8 & 93.7 & $20-80$ & $60-70$ \\
\hline Carnosine & 4.0 & 6.6 & & & & & \\
\hline Arginine & 66.8 & 83.0 & 82.7 & 117 & 102 & $20-90$ & $30-60$ \\
\hline Argininosuccinic acid & & & & & 64.6 & & \\
\hline
\end{tabular}

family I propositus also showed a peak of argininosuccinic acid anhydride $B$, which could not be quantitated.

Citrulline, the urea cycle intermediate anterior to argininosuccinic acid, is generally elevated in the two families. There is a particularly higher level in the two propositi. Family I propositus shows $240 \mu \mathrm{M}$ citrulline, as compared to $47.4-65.8 \mu \mathrm{M}$ in other family members. In family II, the propositus has a citrulline level of 173 against $68.6-133$ in parents and siblings. The plasma citrulline and argininosuccinic acid levels in the propositi show a similar trend. 
Glutamine, another amino acid of particular importance in ammonia detoxication, is generally elevated. In family I it has the highest level in the propositus at $1373 \mu \mathrm{M}$ as against 371$437 \mu \mathrm{M}$ in the parents and sibling. The family II figures range from 526 to $911 \mu \mathrm{M}$, with the sister of the propositus showing the highest glutamine level. These values indicate a generalized disturbance in ammonia metabolism. The plasma arginine level in members of both families is normal probably due to normal enzyme levels in some of the organs.

Plasma urea nitrogen, ranged between 7.1 to $13.3 \mathrm{mg} / \mathrm{dl}$ in family I and 7.7-11.7 mg/dl in family II. The propositi had 9.6 and $11.1 \mathrm{mg} / \mathrm{dl}$, respectively, which is within normal fasting range. Despite the enzyme block in the urea cycle, the patients with argininosuccinic aciduria have shown normal urea nitrogen concentrations in the plasma (11). Measurement of plasma $\mathrm{NH}_{3}$ was not attempted due to considerable time lapse between sampling and analysis.

\section{NUTRITIONAL AND METABOLIC STUDIES}

As family I was not readily accessible, the dietary protein loading trial was conducted on members of family II, along with a carefully selected control family. Table 6 shows the results of this trial, which was designed to study the urinary nitrogen excretion pattern due to disturbed ammonia metabolism in the affected family. The urinary urea excretion in the affected family ranged between 6.9 and $15.9 \mathrm{mg} / \mathrm{mg}$ creatinine, as compared to 9.4-15.1 in the control family. The urinary ammonia excretion at $0.410-2.089 \mathrm{mg} / \mathrm{mg}$ creatinine in the affected family was much higher than $0.137-0.222 \mathrm{mg}$ excreted by the control family.

Since we have evidence of a good linear correlation $(r=$ $0.79)$ between the protein intake $(1.0-3.0 \mathrm{~g} / \mathrm{kg}$ body $\mathrm{wt}$ ) and urinary urea and ammonia excretion (28), we equilibrated the varied protein intake of all family members by calculating the figures on a per gram protein-intake basis. The data presented in Table 6 show that, although the urea excretion pattern was apparently similar, 3-5 times more ammonia was excreted by the affected family members as compared to controls. The propositus excreted 15-20 times more ammonia than the control family and 3-5 times more than the members of the affected family.

The excretion of orotic acid in the affected family members ranged from 0.98 to $4.2 \mu \mathrm{g} / \mathrm{mg}$ creatinine as compared to control Family figures of $0-2.48$, all within the normal level of $6.8 \pm 5.54 \mu \mathrm{g} / \mathrm{mg}$ creatinine (18).

\section{EXCRETION OF URINARY AMINO ACIDS IN FAMILY II}

A part of the urine samples obtained from affected family II was analyzed for aminoaciduria. The results of $\alpha$-amino nitrogen measurement showed a level of $1.15 \mathrm{mg} / \mathrm{mg}$ creatinine in the propositus as compared to $0.23-0.51$ in the parents and siblings.
Calculated on the basis of per $g$ protein intake, the figures showed approximately 4-5 times (0.76) more $\alpha$-amino nitrogen excretion in the propositus as compared to parents and siblings (0.14-0.20).

Only the propositus showed a urinary excretion of argininosuccinic acid of the level of $126 \mathrm{mg} / \mathrm{dl}$ urine. Anhydrides B and $C$ were also seen in the chromatogram, but could not be quantitated. However, anhydride $C$ had 7.06 times more surface area than anhydride $B$. Nothing remarkable was seen in the excretion pattern of other amino acids.

\section{DISCUSSION}

Both the affected families studied in this paper provide another example of the autosomal recessive inheritance of argininosuccinic aciduria. The parents in both families are obligate heterozygotes, showing $37-42 \%$ of erythrocyte ASAL activity. The propositi are of different sexes, with male and female heterozygous siblings. However, we did not find any normal sibling. This situation is not beyond the limits of probability. The sibling number has to be considerably larger to achieve the theoretic incidence of $2: 1: 1$ for heterozygotes, normal homozygotes and homozygous abnormals in the autosomal recessive pattern of gene transmission.

No residual enzyme activity was seen in red blood cells of the family II propositus, which corresponds to most of the published observations in studied cases. However, there was $13 \%$ of erythrocyte ASAL activity in the propositus of family $\mathrm{I}$. To our knowledge, very few cases with residual RBC enzyme have been reported. Glick et al. (17) found $17 \%$ of control activity in his patient who died of neonatal argininosuccinic aciduria. Shih et al (31) have reported $0-5 \%$ and $0-10 \%$ of activity in two of the six children, who were being followed up for this disease after newborn screening in the state of Massachusetts. This points towards the heterogeneity of mutant or residual enzymes in the children studied so far. However, the difference in methodology used by Glick et al. (17) and ourselves would also be a contributing factor toward this variation.

The fasting plasma levels of argininosuccinic acid in the two propositi did not correlate with the levels of ASAL in erythrocytes. There was $210 \mu \mathrm{M}$ argininosuccinic acid with indications of anhydride $\mathrm{B}$ content in the family I propositus, with an enzyme activity of $13 \%$; while the family II propositus gave an argininosuccinic acidemia reading of $64.6 \mu \mathrm{M}$ with no activity of RBC ASAL. Plasma glutamine and citrulline levels were also much more elevated in the family I propositus. This situation is understandable since the absence of RBC ASAL has not always been associated with an acute form of argininosuccinic aciduria syndrome. The clinical disease seems to be the result of an adverse balance of ASAL activity in various organs and tissues, with liver enzyme being the deciding factor. Recent report of an acute case of argininosuccinic aciduria (17) would support this

Table 6. Pattern of urinary urea and ammonia excretion after protein loading in affected family II as compared to control family

\begin{tabular}{|c|c|c|c|c|c|c|c|}
\hline $\begin{array}{l}\text { Family } \\
\text { members }\end{array}$ & $\begin{array}{c}\text { Age } \\
\text { (years) }\end{array}$ & $\begin{array}{c}\text { Body wt, } \\
\text { kg }\end{array}$ & $\begin{array}{l}\text { Protein in- } \\
\text { take, } \mathrm{g} / \mathrm{kg} \\
\text { body wt }\end{array}$ & $\begin{array}{l}\text { Urinary urea ex- } \\
\text { cretion, } \mathrm{mg} / \mathrm{mg} \\
\text { creatinine }\end{array}$ & $\begin{array}{l}\text { Urinary } \mathrm{NH}_{3} \text { ex- } \\
\text { cretion, } \mathrm{mg} / \mathrm{mg} \\
\text { creatinine }\end{array}$ & $\begin{array}{c}\text { Urinary urea, mg/ } \\
\text { mg creatinine } / \mathrm{g} \\
\text { protein intake }\end{array}$ & $\begin{array}{c}\text { Urinary } \mathrm{NH}_{3}, \mathrm{mg} / \\
\text { mg creatinine/g } \\
\text { protein intake }\end{array}$ \\
\hline \multicolumn{8}{|l|}{ Affected family } \\
\hline Father & 40 & 60.9 & 1.6 & 6.90 & 0.584 & 4.31 & 0.365 \\
\hline Mother & 33 & 58.2 & 1.5 & 9.38 & 0.410 & 6.25 & 0.270 \\
\hline Male sibling & 10 & 22.7 & 3.1 & 15.88 & 0.882 & 5.12 & 0.285 \\
\hline Female sibling & 7 & 26.8 & 2.6 & 12.60 & 0.787 & 4.85 & 0.303 \\
\hline Propositus & 3 & 13.2 & 1.5 & 10.76 & 2.089 & 7.18 & 1.393 \\
\hline \multicolumn{8}{|l|}{ Control family } \\
\hline Father & 41 & 75.0 & 1.2 & 9.35 & 0.141 & 7.79 & 0.118 \\
\hline Mother & 37 & 52.3 & 1.6 & 9.52 & 0.137 & 5.95 & 0.086 \\
\hline Male child & 12 & 36.8 & 2.5 & 13.25 & 0.222 & 5.30 & 0.089 \\
\hline Female child & 11 & 30.9 & 2.8 & 12.30 & 0.193 & 4.39 & 0.069 \\
\hline Male child & 6 & 20.9 & 2.7 & 15.05 & 0.204 & 5.58 & 0.076 \\
\hline
\end{tabular}


contention. In this child, who died at 6 days of age, there was a $17 \%$ residual activity of $\mathrm{RBC}$ enzyme; the brain and kidney enzymes were nearly normal whereas the liver enzyme was almost absent

Our present study on the kinetics of the RBC ASAL in affected families has yielded interesting data. To our knowledge, this is the first study of its kind and may lend itself well to present and future interpretations of the nature of the enzyme defect and other important questions involved. The details of different plots of kinetic data and the statistical methodology used has already been discussed under Results. The figures of statistical comparison in Table 2 confirm the presence of a reduced enzyme activity in all the members of affected families due to a significantly reduced $\mathrm{V}_{\max }$ value, as compared to control. There is no significant difference between the control and affected subjects in respect of $K_{m}$ values. This may mean that there are no remarkable structural differences between the normal control enzyme and the enzyme from affected family members, but the quantity of available enzyme molecules differs.

The statistical comparison within family members, shown in Table 3 , brings up a contrast between the two affected families. Within family $\mathrm{I}$, the differences are solely determined by the $V_{\max }$ value of the enzyme. There is a significantly reduced velocity in the propositus as compared to all other family members and in mother and brother as compared to father. Since structural differences do not seem to be important, this could be interpreted to mean that the level of induced normal enzyme due to dietary or other factors was much different than each other in these heterozygotes at the time of hematopoiesis. The point activity measurement, $42 \%$ in the father against $40 \%$ and $33 \%$ in mother and sibling, would be in line with this argument

Within family II, almost all the differences are determined by a variation of $K_{m}$ values. There are no significant differences within the parents and within the two siblings, indicating a structural similarity in each case. However, there is a significant difference seen (generally $P<0.01$ ) when each parent is compared against each child. The two siblings have a significantly reduced $\mathrm{K}_{\mathrm{m}}$ value as compared to the parents $(0.09$ and 0.10 against 0.16 and $0.18 \mathrm{mM}$ ). This heterogeneity of enzyme structure or expression, between the obligate heterozygotes and heterozygote siblings, is hard to understand. It cannot be explained on the basis of different structural enzyme entities inherited from father and mother since there is no statistical difference between the parents. Yet the similarity of $K_{m}$ values in the two siblings lends strong support to the probability that the enzyme has been inherited from the two parents. Unfortunately, it was not possible to study the kinetics of the enzyme in the propositus of this family, due to no activity shown. Any such study might have thrown some light on the issue. Under the circumstances we can only venture to postulate that the enzyme structure has somehow been adapted to the metabolic needs of quick growth in the face of reduced enzyme content in the tissues involved.

Glick et al (17), in their recent article, have presented evidence to demonstrate that more than one gene either codes for the structure of ASAL or regulates its activity in different tissues. Although some evidence is available (11) on the difference of ASAL structure in human kidney and liver, we will have to wait for studies made on purified enzymes from human organs to know whether there are similarities in the structure of enzyme from various tissues. Such a similarity would support the hypothesis of Glick et al (17), who postulate that different regulatory genes may be involved in controlling the level of ASAL in various organs. The statistical data on RBC ASAL kinetics presented by us is generally in line with the regulatory gene hypothesis. It demonstrates that the preponderance of maximal velocity differences in the enzyme taken from deficient erythrocytes results from the presence of residual normal molecules rather than structurally altered enzyme.
Increased levels of citrulline in the plasma of affected families, particularly in the two propositi, indicate the presence of a feedback inhibition by argininosuccinic acid of argininosuccinate synthetase, the enzyme anterior to ASAL in the urea cycle. The citrulline level also suggests that the mitochondrial enzymes of the urea cycle are intact. This is supported by a near normal level of urinary orotic acid in family II. Plasma glutamine levels are the result of a disturbed ammonia detoxication in members of both families. Recent research has indicated that even in normal acid-base conditions the amount of glutamine available to the kidney can alter the rate of ammonium excretion in urine which is proportional to the level of plasma glutamine (37).

The presence of increased plasma argininosuccinic acid and its anhydrides only in the propositi of the two affected families would mean that the residual ASAL activity in the tissues of the heterozygotes is sufficient to metabolize the available argininosuccinic acid. A protein load of moderate proportions was also not able to induce argininosuccinic aciduria in the heterozygotes of family II, although it brought about a high excretion of argininosuccinic acid in the propositus.

The present study has given an interesting picture of the kinetics of RBC ASAL in two families affected by argininosuccinic aciduria but has not provided answers to many important questions. One of these is: just what is the importance, individual or interdependent, of the RBC ASAL in the whole scheme of things? This question has a bearing on current and future research on argininosuccinic aciduria, since erythrocyte enzyme, because of its easy accessibility, would be used increasingly to confirm the diagnosis of inherited disease. A comprehensive answer to this question would involve painstaking work on the structural and kinetic characterization of human enzyme from various organs and tissues in its normal and abnormal forms, and an integrated study at the biochemical, metabolic, and clinical levels.

\section{REFERENCES AND NOTES}

1. Adachi, T., Tanimura, A., and Asahina, M.: A colorimetric determination of orotic acid. J. Vitaminol., 9: 217 (1963).

2. Adams, C. F.: Nutritive value of american foods in common units. In: USDA Agricultural Handbook No. 456 (U.S. Government Printing Office, Washington D.C., 1975).

3. Allan, J. K., Cusworth, D. C., Dent, C. E., and Wilson, V. K. A disease, probably hereditary, characterized by severe mental deficiency and a gross abnormality of amino acid metabolism. Lancet, $i: 182$ (1958).

4. Applegarth, D. A., Davidson, C. F., Perry, T. L., Poon, S., Crichton, J. U and Hardwick, D. F.: Argininosuccinic acidemia in a healthy infant detected by a urine screening program [Abstr.]. Clin. Chem., 21: 950 (1975).

5. Baumgartner, R., Schneider, S., Stalder, G., and Hottinger, A.: Neonata death due to argininosuccinic aciduria. Helv. Pediat. Acta, 23: 77 (1968)

6. Beckman/Spinco: Technical Bulletin No. 6080: Creatinine (Beckman Instruments Co., Palo Alto, CA, 1961).

7. Billmeier, G. J., Molinary, S. V., Wilroy, R. S., Duenas, D. A. and Brannon, N. E.: Argininosuccinic aciduria: Investigation of an affected family. J. Pediat., 84: 85 (1974)

8. Carton, D., De Schrijver, F., Kint, J., Van Durme, J., and Hooft, C. Argininosuccinic aciduria: Neonatal variant with rapid fatal course. Acta. Pediat. Scand., 58: 528 (1969)

9. Cederbaum, S. D., Shaw, K. N. F., Valente, M., and Cotton, M. E. Argininosuccinic aciduria. Amer. J. Ment. Def., 77: 395 (1973).

10. Ceriotti, G.: Ultramicro determination of plasma urea by reaction with diacetyl monoxime antipyrine without deproteinisation. Clin. Chem., 1\%: 400 (1971).

11. Colombo, J. P.: Argininosuccinic aciduria. In: Congenital Disorders of the Urea Cycle and Ammonia Detoxication, p. 67 (S. Karger, Basel, 1971).

12. Dixon, M., and Webb, E. C.: Enzyme kinetics. In: Enzymes, p.54 (Long mans, London, 1964)

13. Dixon, W. J., and Massey, F. J., Jr.: Regression and correlation. In: Introduction to statistical analysis, p. 193 (McGraw Hill, New York, 1969)

14. Edkins, F., and Hockey, A.: A case of argininosuccinic aciduria. Fourth Annual Interstate Conference on Mental Deficiency, p. 54 (Melbourne, 1965).

15. Farrel, G., Rauschkolb, W., Moure, J., Headlee, R. E., and Moser, M. D. Argininosuccinic aciduria. Texas Med., 65: 90 (1969).

16. Farriaux, J. P., Cartigny, B., Dhondt, J. L., Kint, J., Louis, J., Delattre, P. and Fontaine, G.: A neonatal observation of argininosuccinic aciduria. Acta. Pediat. Belg., 28: 1939 (1974)

17. Glick, N. R., Snodgrass, P. J., and Schafer, I. A.: Neonatal argininosuccinic aciduria with normal brain and kidney but absent liver argininosuccinate lyase activity. Amer. J. Hum. Gen., 28: 22 (1976). 
18. Goldstein, A. S, Hoogenraad, N. J., Johnson, J. D., Fukanaga, K., Swierczewski, E., Cann, H. M., and Sunshine, P.: Metabolic and genetic studies of a family with ornithine transcarbamylase deficiency. Pediat. Res., 8: 5 (1974).

19. Hartlage, P. L., Coryell, M. E., Knowlton-Hall, W., and Hahn, D. A.: Argininosuccinic aciduria: Perinatal diagnosis and early dietary management. J. Pediat., 85: 86 (1974).

20. Lemieux, B.: Personal communication

21. Levin, B.: Argininosuccinic aciduria. Amer. J. Dis. Child., 113: 162 (1967).

22. Moser, H. W., Efron, M. L., Brown, H., Diamond, R., and Neumann, C. G.: Argininosuccinic aciduria: Report of two new cases and demonstration of intermittent elevation of blood ammonia. Amer. J. Med., 42: 9 (1967).

23. Nutrition Today Society: Infant screening for inborn errors of metabolism. Nutr. Today, 9: 21 (1974).

24. Orion Research: Instruction Manual for Ammonia Electrode: Model 95-10 (Orion Research Instruments, Cambridge, MA, 1974)

25. Palmer, T., Oberholzer, V. G., Levin, B., and Ann Burgess, E.: Urinary excretion of argininosuccinic acid. Clin. Chim. Acta, 47: 443 (1973).

26. Pollitt, R. J.: Argininosuccinate lyase levels in blood, liver and cultured fibroblasts of a patient with argininosuccinic aciduria. Clin. Chim. Acta, 46: 33 (1973).

27. Potter, J. L., Timmons, G. D., and Silvidi, A. A.: Argininosuccinic aciduria, the hair abnormality. Amer. J. Dis. Child., 127: 724 (1974).

28. Qureshi, I. A., Letarte, J., and Ouellet, R.: Submitted for publication.

29. Scriver, C. R., and Rosenberg, L. E.: Methods of analysis and diagnosis of aminoacidopathies. In: Amino Acid Metabolism and Its Disorders, p. 95 (W. B. Saunders Co., Philadelphia, 1973)

30. Shih, V. E.: Early dietary management in an infant with argininosuccinase deficiency: Preliminary report. J. Pediat., 80: 645 (1972).

31. Shih, V. E., Coulombe, J. T., Carney, M. M., Madigan, P. M., and Erickson, A. M.: Argininosuccinic aciduria detected by routine screening [Abstr.]. Pediat. Res., 10: 371 (1976).

32. Shih, V. E. and Efron, M. L.: Urea cycle disorders. In: The Metabolic Basis of Inherited Disease, p. 370 (McGraw Hill, New York, 1972).

33. Shih, V. E., Jones, T. C., Levy, H. L., and Madigan, P. M.: Arginase

Copyright (C) 1978 International Pediatric Research Foundation, Inc. $0031-3998 / 78 / 1204-0256 \$ 02.00 / 0$ deficiency in Macaca fascicularis. 1. Arginase activity and arginine concentration in erythrocytes and liver. Pediat. Res. 6: 148 (1972).

34. Takahara, K., and Natelson, S.: Argininosuccinic acid lyase in human erythrocytes and plasma in health and disease. Amer. J. Clin. Path., 47: 693 (1967).

35. Tomlinson, S., and Westall, R. G.: Argininosuccinic aciduria, argininosuccinase and arginase in human blood cells. Clin. Sci., 26: 261 (1964).

36. Wagstaff, T. I., Ann Burgess, E., Oberholzer, V. G., and Palmer, T.: Argininosuccinic aciduria: Antenatal investigations in an affected family. Amer. J. Obstet. Gynecol., 120: 560 (1974)

37. Welbourne, T., Weber, M. and Bank, N.: The effect of glutamine administration on urinary ammonium excretion in normal subjects and patients with renal disease. J. Clin. Invest., 51: 1852 (1972).

38. Wells, M. G.: A simple rapid method for the determination of $\alpha$-amino acids in urine. Clin. Chim. Acta, 25: 27 (1969).

39. Informed consent was obtained from parents of both affected families.

40. These results were reported in part at the Annual Meeting of the Canadian Society for Clinical Investigation, Toronto, Ontario, January 25-26, 1977 (Clin. Res., 24: 682A (1976)).

41. We wish to thank Mme Francine Poisson, Mr. Robert Giguere, and Mme Vivian Troche for excellent technical assistance. We acknowledge the expert secretarial assistance by Mme Elizabeth B. Cordeau and Mlle Francine Gingras.

42. Dr. I. A. Qureshi is recipient of a research fellowship from le Conseil de la Recherche en Santé du Québec, Montréal.

43. This research was supported in part by the Foundation Justine-LacosteBeaubien, Montreal, Québec, and the Quebec Network of Genetic Medicine.

44. Requests for reprints should be addressed to: J. Letarte, M.D., Laboratoires d'Endocrinologie, Métabolisme et Nutrition, Centre de Recherche Pédiatrique, Hôpital Ste-Justine, 3175 Chemin Ste-Catherine, Montréal H3T 1C5, P.Q. (Canada).

45. Received for publication March 14, 1977

46. Accepted for publication July $27,1977$. 